А. А. Проценко, В. Г. Іванов

Харківський національний університет радіоелектроніки, Харків, Україна

\title{
КЛАСИЧНІ МЕТОДИ ПЛАНУВАННЯ ШЛЯХУ ДЛЯ МОБІЛЬНИХ РОБОТІВ
}

\begin{abstract}
Мобільні автономні роботи (МАР) використовуються для виконання великої кількості різноманітних завдань у різних галузях, таких як видобуток корисних копалин, пошук та порятунок, військових застосувань тощо. Окремо виділяється категорія МАР, які використовуються у закритих приміщеннях. Це пов'язано з додатковими технічними та програмними обмеженнями які накладаються на МАР та оператора. У цій статті розглядаються 35 класичних методів пошуку шляху для МАР та методів їх оптимізації. Класичні методи включають наступні категорії методів: методи клітинної декомпозиції; методи штучного потенційного поля; вибіркові методи; методи, що використовують мережу проміжних задач. У статті також розглядаються основні проблеми, що виникають під час виконання задачі пошуку шляхів. Методи аналізувалися за такими характеристиками: обмеження; режим планування; мнтрика, яка використовується для планування наступного кроку. Також у статті розглядаються основні проблеми з якими стикаються під час виконання задачі пошуку шляху.
\end{abstract}

Ключ ов і слов а: МАР, роботи, автономність, пошук шляху, планування руху.

\section{Ветуп}

Робота людини у тунелях, шахтах та інших підземних просторах завжди пов'язана з великою кількістю ризиків для життя людини [1]. Використання МАР допомагає зменшити ці ризики, за рахунок попередження про них [2], або зменшити наслідків подій, які випливають з цих ризиків [3]. Проблема переміщення роботів з точки $A$ у точку $B \in$ базовою проблемою яка стосується усіх роботів, але під час використання у підземних структурах вирішення цієї проблеми ускладнено наявністю додаткових факторів, таких як відсутність зв'язку з оператором та неможливість використання систем GPS.

У цій роботі розглядаються існуючі класичні методи планування шляху для МАР. Класичні методи знаходять рішення проблеми пошуку шляху, або доводять що, його не існує, без знаходження компромісу між якістю шляху та кількістю часу/ресурсів потрібних на його знаходження. Не дивлячись на це, класичні методи $є$ популярним для виконання реальних задач пошуку шляху, та використовуються як основа для більш розвинутих методів.

Метою даної роботи $є$ аналіз існуючих класичних методів планування шляху для визначення доцільності їх використання у закритих приміщеннях.

\section{Виклад основного матеріалу}

До класичних відносяться такі методи:

- методи клітинної декомпозиції;

- методи штучного потенційного поля;

- вибіркові методи;

- методи, які використовують мережу проміжних задач.

У більшості методів пошуку шляху використовуються наступні поняття: світовий простір, конфігураційний простір $\left(C_{\text {space }}\right)$ та вільний простір $\left(C_{\text {free }}\right)$. Світовий простір відноситься до фізичного простору, в якому існують роботи та перешкоди. Конфігурація об'єкта заданої форми є сукупністю незалежних параметрів, що характеризує положення кожної точки в об'єкті. Кількість параметрів, що визначають конфігурацію об'єкта, називається ступенями свободи об'є- кта. Набір всіх конфігурацій називається конфігураційним простором. Вільний простір відноситься до частин світового простору, не зайнятих перешкодами. або частини простору $C_{\text {space }}$, у яких робот не стикається 3 жодною перешкодою [4]. Загальна задача пошуку шляху передбачає знаходження неперервного шляху роботу через простір $C_{f r e e}$.

\section{Методи клітинної декомпозиції}

Клітинна декомпозиція базується на принципі розподілу простору $C_{\text {space }}$ на клітини: ділянки простору з спільними перегородками. Клітини розділяються на вільні та зайняті, на яких відмічаються опорні точки для формування графу, на якому вирішується задача комівояжера. Первинним кроком цих алгоритмів $\epsilon$ розбиття вільного конфігураційного простору $C_{\text {free }}$ на набір пустих опуклих ділянок $K_{\text {void. }}$ Методи клітинної декомпозиції розділені на три категорії: точні, наближені та імовірнісні (рис. 1).

\section{Точна декомпозиція}

У точних методах набір ділянок $K_{\text {void }}$ точно співпадає 3 вільним конфігураційним простором робота, тобто $K_{\text {void }}=C_{\text {free }}$. Найвідомішим методом точної декомпозиції є запропонований Latombe метод трапецоїдної декомпозиції [5], на якому базуються розроблений Choset метод декомпозиції бустирофедоном [6] та запропонований Atkar метод декомпозиції Морса [7]. Також існують методи оптимізації точного підходу за рахунок використання різних метрик ([8], рис. 2) та оптимізації шляху за рахунок використання покриваючого графу [9], які допомагають збільшити ефективність даного підходу.

\section{Наближена декомпозиція}

Для наближених методів $K_{\text {void }}$ є обмеженим наближенням вільного конфігураційного простору, тобто $K_{\text {void }} \in C_{\text {free }}$. Клітини у цьому підході відрізняються від клітин у точному підході тим, що клітини тепер повинні мати просту форму, наприклад, прямокутну. Обгрунтування стандартизації форми клітин полягає в досягненні розбиття простору через повторення тих ж самих простих обчислень [5]. 

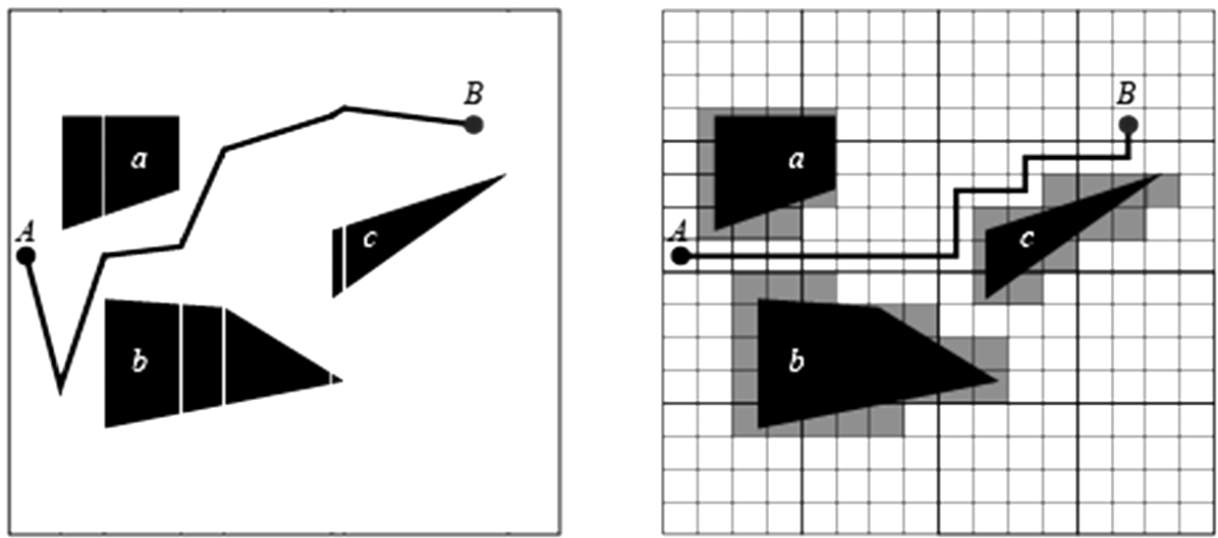

Рис. 1. Різниця між точною (зліва) та наближеною (справа) декомпозицією. Умовні позначення: $A$ - початок шляху, $B$ - пункт призначення , $a, b, c-$ перешкоди

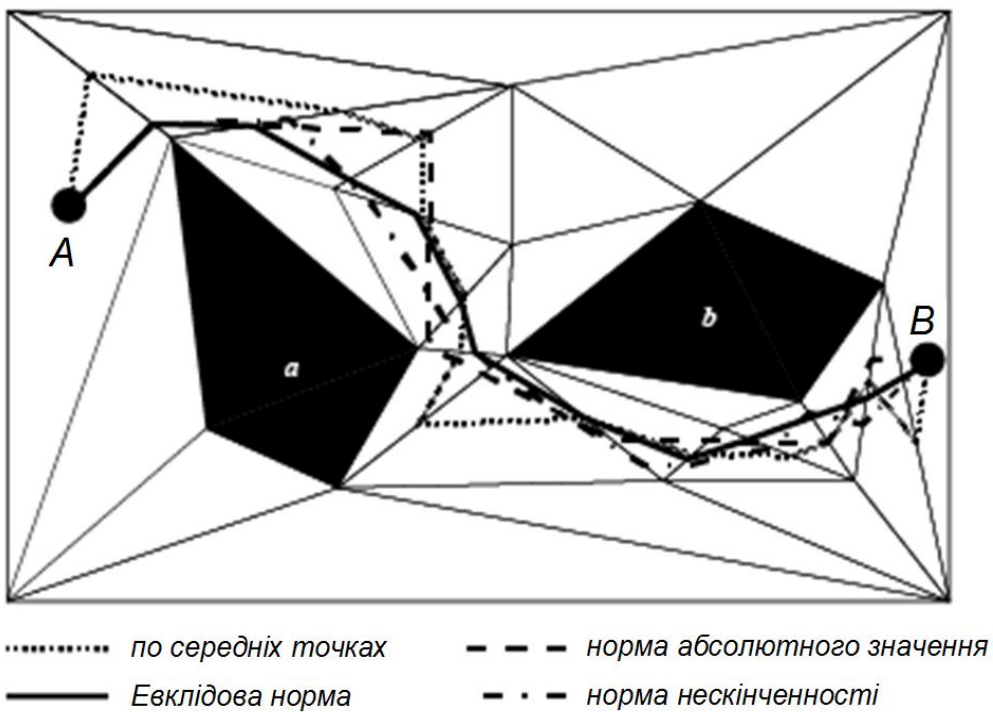

Рис. 2. Різниця між шляхом отриманим за допомогою різних метрик (адаптовано 3 [8]). Умовні позначення: $A$ - початок шляху, $B$ - пункт призначення , $a, b$ - перешкоди

Популярними категоріями наближених методів $\epsilon$ методи, які базуються на приблизній прямокутній декомпозиції $[10,11]$, та методи, які базуються на запропонованому Noborio [12] використанні дерева квадрантів [13, 14]. На основі наближених методів легко побудувати адаптивні методи декомпозиції [15], які можна використовувати за умови відсутності повної мапи на момент початку руху. Процес формування клітин показано на рис. 3 , а. Оточуюче середовище сканується за допомогою лазерного далекоміру. За результатами сканування у радіусі зчитування $r$ формується клітина $C_{k}$. Межі цієї клітини являють собою межі діапазону чутливості, при яких лінія сканування не зустрічається 3 будь-яким іншим об'єктом під час переміщення по всій області чутливості. На рис. 3, б вибірка робочого простору має з більше ознак, такі як лінії і криві. Інформація про клітину отримується легко при зустрічі лінії сканування з будь-якою з цих ознак.

\section{Імовірнісна декомпозиція}

Імовірнісні методи базуються на наближених, тобто всі клітини мають заздалегідь визначену форму, а межі клітин не обов'язково мають фізичне зна- чення. Основною різницею $є$ те, що у імовірнісних методах клітина не перевіряється, але вважається вільною, доки це не буде спростовано. Клітина називається можливо вільною, якщо всі перевірки зіткнень зразків у цій клітині мають негативний результат. Відповідно, вона називається можливо зайнятою, якщо всі перевірки $є$ позитивними. Якщо клітина має одночасно негативний і позитивний результат, вона називається змішаною і повинна бути розбита на можливо вільні та можливо зайняті клітини [16]. Запропонований Rosell [17] комбінований метод використовує гармонічні функції для планування шляху конфігураційному просторі великих масштабів.

\section{Методи штучного потенційного поля}

Метод штучного потенційного поля розроблений Khatib [18] для маніпуляторів та мобільних роботів. У цьому методі вважається, що робот рухається в абстрактному штучному силовому полі (рис. 4). Це поле складається 3 відштовхуючого потенційного поля, яке створюють перешкоди, та притягального потенційного поля, яке створює кінцева точка шляху. 


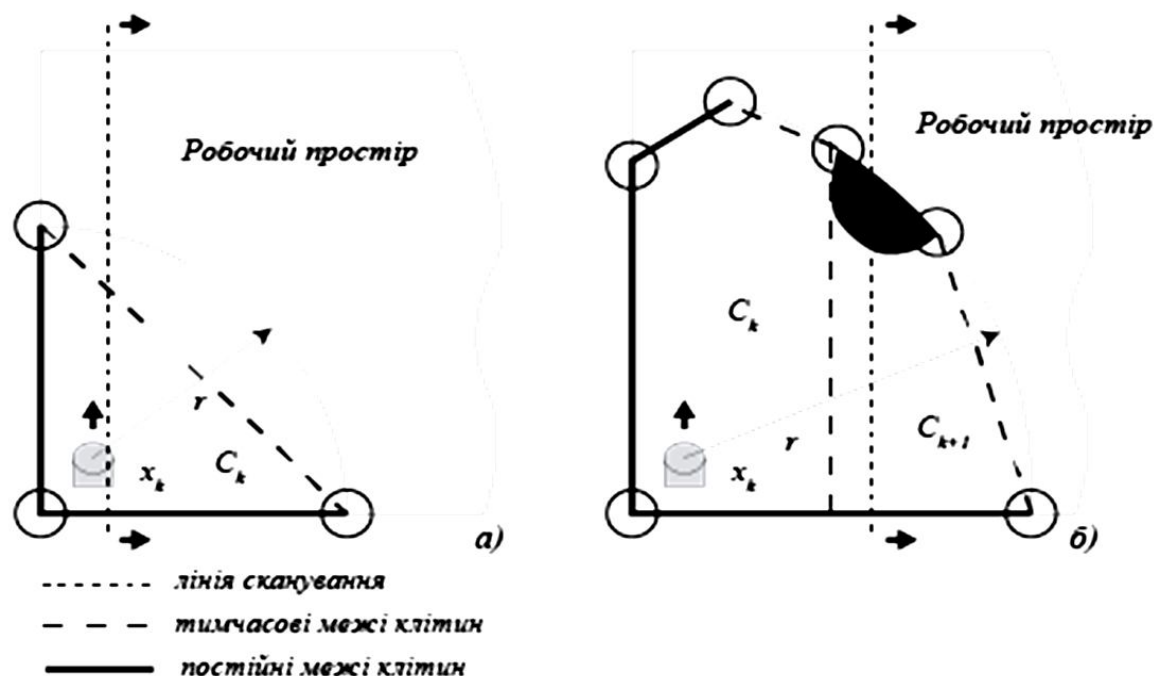

Рис. 3. Формування клітин при адаптивній декомпозиції (адаптовано 3 [15]). Умовні позначення: $x_{k}$ - положення роботу, $r$ - радіус зчитування, $C_{k}, C_{k+1}-$ клітини

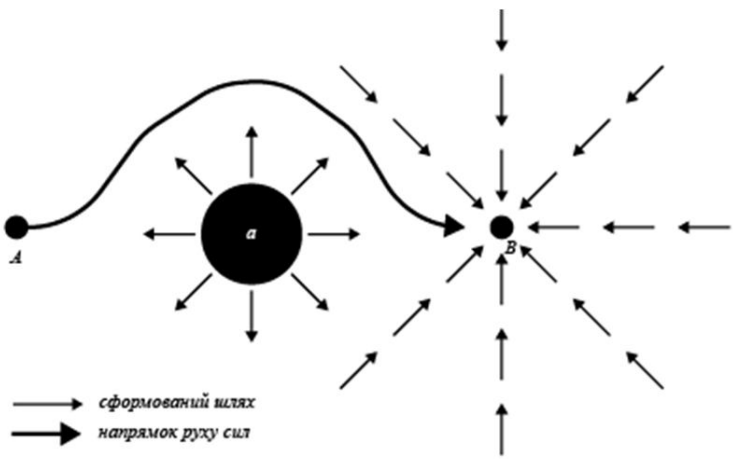

Рис. 4. Формування шляху мобільного роботу через абстрактне штучне потенційне поле.

Умовні позначення: $A$ - положення роботу, $B$ - пункт призначення, $a$ - перешкода

Головною перевагою методу штучного потенційного поля є простота у виконані, а серед недоліків виділяється незручність застосування для динамічних середовищ та існування локальних мінімумів потенціалів, що може привести до неможливості досягання кінцевої точки. Обидві проблеми були адресовані Ge та Cui ([19], рис. 5), які запропонували метод, у якому потенційні функції враховують не тільки відносне положення робота щодо цілі та перешкод, але й також відносні швидкості робота щодо цілі та перешкод. Відповідно, віртуальна сила визначається як негативний градієнт потенціалу стосовно як положення, так і швидкості. Вирішення проблеми локального мінімуму виконується наступним чином: коли робот виявляє, що він і кінцева точка $є$ у межах впливу перешкоди, а кінцева точка знаходиться між роботом і кінцевою точкою, потенціал відштовхуючого потенційного поля вважається за 0, тобто на робота діє тільки притягальне поле.

Альтернативне вирішення проблеми локальних мінімумів через створення тимчасових локальних цілей запропоноване у [20]. Комбінування методу потенційного поля 3 штучним інтелектом дозволяє створювати нові, більш ефективні методи планування шляху, такі як запропонований Vadakkepat метод еволюційного штучного потенційного поля [21].

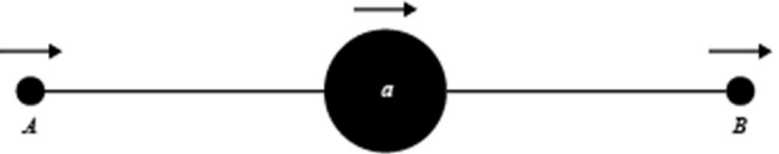

Рис. 5. Проблема локального мінімуму (адаптовано 3 [19]).

Умовні позначення: $A$ - положення роботу, $B$ - пункт призначення , $a$ - перешкода

У цьому методі, еволюційний алгоритм використовується для оптимізації потенційних функцій поля перешкод. Це допомагає створити більш гладкий та оптимальний шлях, порівняно з традиційним методом. Jaradat у [22] запропонував новий підхід розроблений з використанням експертної системи на основі нечіткої логіки. Притягальні та відштовхуючі сили представлені за допомогою експертних if-then правил. Перевага цього підходу виявляється у можливості забезпечити безперешкодний шлях для робота та рішення проблеми локального мінімуму у будь-якому стаціонарному та динамічному середовищі в порівнянні з іншими методами. Методи штучного потенційного поля придатні для використання 3 мультиагентними системами [22-24].

\section{Вибіркові методи}

Вибіркові методи унікальні в тому, що планування відбувається шляхом вибірки конфігурації простору. Методи на основі вибірки не гарантують знаходження рішення, якщо таке існує, тобто вони не надають повноти. Натомість, вони забезпечують більш слабке уявлення про повноту - імовірнісну повноту. Рішення буде надано, якщо воно існує, за умови достатнього часу виконання алгоритму (в деяких випадках можливий нескінченний час виконання) [25]. Latombe у [26] запропонував новітній алгоритм пошуку шляху який базувався на випадковій вибірці комбінованій з методом штучних потенційних полів. Даний метод обчислює чисельні потенційні поля в конфігураційному просторі, які мають дуже мало або незначні локальні мінімуми, 3 яких робот може врятуватися за допомогою двох 
типів алгоритмів, перший з яких базувався на пошуку грубою силою, другий - на методі Монте-Карло. Основними напрямкам вибіркових методів $є$ методи на основі дорожніх карт та швидко-досліджуючих випадкових дерев. Також можна відзначити методи на основі клубку Аріадни [27] та експансивних просторових дерев [28].

\section{Дорожня карта}

Дорожня карта - це неорієнтований граф $R=(N ; E)$. Вузли в $N$ - це набір конфігурацій робота, який правильно вибрано у $C_{f r e e}$. Ребра в $E$ відповідають простому шляху; ребро між двома вузлами відповідає можливому шляху, який з'єднується 3 відповідною конфігурацію. У 1985 році були запропоновані методи планування шляху які використовували графи видимості [29] та діаграми Вороного [30]. У 1996 році декілька авторів запропонували принципово новий метод планування шляху під назвою імовірнісна дорожня карта $[31,32]$. Незважаючи на те, що підходи мають принципові відмінності, загальний алгоритм дуже схожий та складається 3 двох фаз. На початку фази навчання, або попередньої обробки, для поточної сцени імовірнісно будується структура даних під назвою дорожня карта. На етапі запиту, дорожня карта використовуються для вирішення окремих завдань планування шляху у вхідній сцені. Використовуючи початкову конфігурацію $q_{\text {init }}$ та кінцеву конфігурацію $q_{\text {goal }}$, цей метод спочатку намагається під'єднати $q_{\text {init }}$ та $q_{\text {goal }}$ до деяких вузлів $q$ ' ${ }_{\text {init }}$ та $q$ ' goal у $N$. Якщо цей крок виконано успішно, то алгоритм шукає $R$ на рахунок послідовності ребер у $E$ які з'єднують $q$ 'init та $q$ 'goal. Нарешті, алгоритм перетворює цю послідовність на можливий шлях для робота, перекомпілюючи відповідні локальні шляхи та об'єднуючи їх [33]. Методи на основі імовірнісних дорожніх карт зазвичай класифікуються залежно від того, чи підтримують вони багато запитів, чи тільки один.

Побудова карти для мульти-запитних методів дуже трудомісткий процес, однак після його завершення цю дорожню карту можна багато разів запитувати, щоб шукати траєкторії з будь-якою парою конфігурацій початку/цілі [34]. Реалізації алгоритму для команд роботів представлено у [34 - 36]. Головними проблемами алгоритму на основі дорожніх карт $є$ трудомісткість процесу пошуку локальних шляхів та наявність вузьких проходів у вільному конфігураційному просторі. Для вирішення першої проблеми Bohlin та Kavraki розробили оптимізований алгоритм під назвою Lazy PRM [37], у якому замість побудови карти можливих шляхів будується карта шляхів, можливість яких тільки передбачається.

У [38] запропоновано використання різних типів процесу вибору вузлів, за допомогою нової стратегії Гауссовської вибірки, що значно знижує кількість необхідних зразків, а у [39] використовується послідовність Хальтона для кращого представлення мобільного середовища робота. Для вирішення другої проблеми використовуються методи на разок методу випробування моста [40], що підвищує щільність зразків всередині вузьких проходів.

\section{Швидко-досліджуючі випадкові дерева}

Швидко-досліджуючі випадкові дерева (RRT) це ефективна структура даних та схема вибірки для швидкого пошуку у просторах великого розміру, які мають як алгебраїчні обмеження (що виникають 3 перешкод), так і диференційні обмеження (що виникають 3 неголономності та динаміки). Ключова ідея полягає в тому, щоб зміщувати дослідження в напрямку недосліджених ділянок простору. Для початкової конфігурації $q_{\text {init }}$ дерево з $K$ вершинами будується у $K-1$ кроків, на кожному з яких спочатку обирається випадкова конфігурація $q_{\text {rand }}$. Після вибору $q_{\text {rand }}$ алгоритм шукає найближчу до нього вершину $q_{\text {near }}$, та створює ребро між цими двома вершинами, після чого обирається наступна $q_{\text {rand }}$ (рис. 6). Цей підхід був розроблений LaValle ([41], рис. 7), який пізніше запропонував його вдосконалений варіант [42].

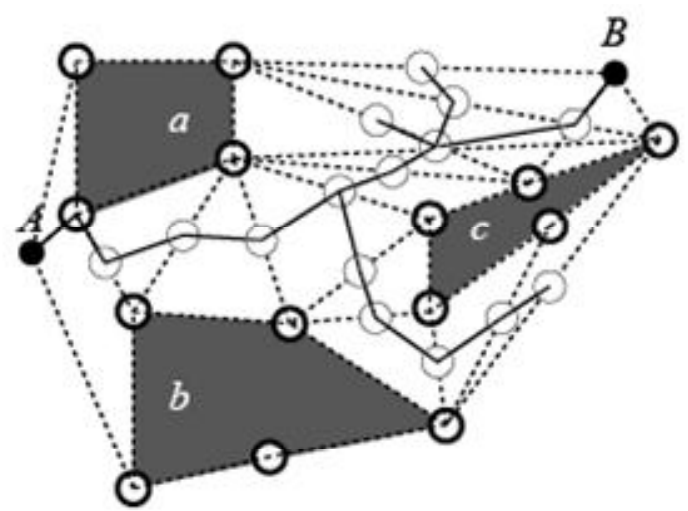

nоди на поеюрхкі перешиход nodu wizexy

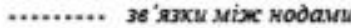
czeroposanwiй แursx
Рис. 6. Отримання шляху для мобільного робота методом, представленим у [33].

Умовні позначення: $A$ - початок шляху, $B$ - пункт призначення , $a, b, c$ - перешкоди

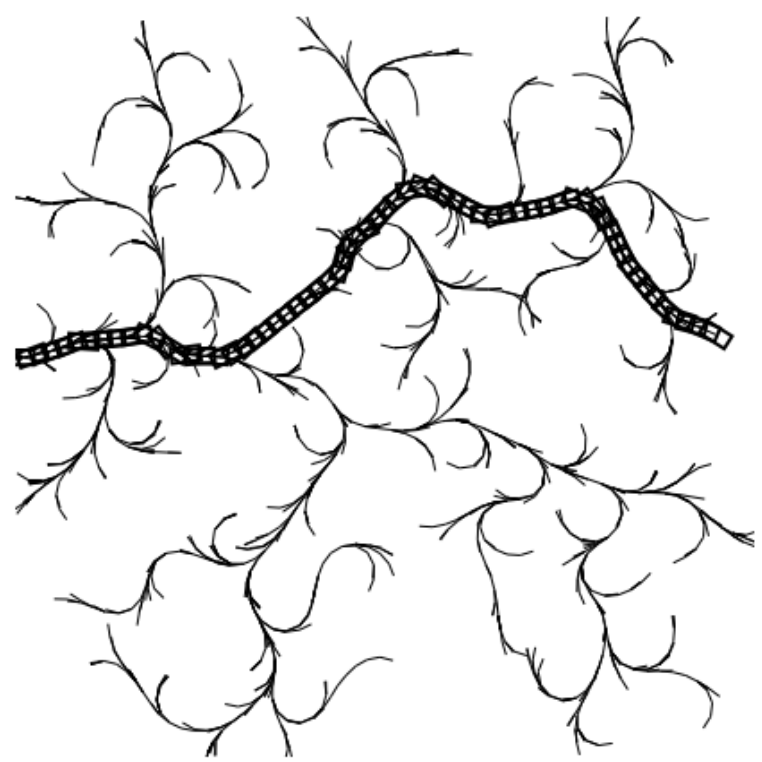

Рис. 7. Швидко-досліджуюче випадкове дерево [41]. Додатково виділено обраний шлях з спроектованими конфігураціями робота 
Urmson та Simmons [43] розробили поліпшені варіанти алгоритму за рахунок урахування вартості шляху. Для боротьби 3 втратою шляху на вузьких ділянках простору, запропоновано алгоритми, який використовують локальні дерева [44], урахування інформації про форму навколишніх перешкод [45], або за рахунок використання двонаправленого алгоритму [42, 46]. Karaman та Frazzoli запропонували нову версію алгоритму під назвою RRT* [47], асимптотично-оптимальну та обчислювально-ефективну версію RRT. Оптимізовані варіанти RRT* представлено у [48, 49]. Ці алгоритми дають швидші результати за рахунок використання поінформованого поступового пошуку [48] та обмеження пам'яті для зберігання дерева [49].

\section{Мережі проміжних цілей (subgoal network)}

Мережі проміжних цілей - це широка категорія різноманітних методів, які перетворюють задачу пошуку основної цілі на задачу пошуку низки шту- чно створених проміжних цілей. Алгоритм для пошуку має наступний вигляд: замість пошуку шляху 3 стартової конфігурації $q_{\text {init }}$ до потрібної конфігурації $q_{\text {goal }}$, шукається деяке число проміжних конфігурацій $q_{\text {subgoal }}$; після переходу роботу до $q_{\text {subgoal }}$, ця конфігурація приймається за $q_{\text {init }}$ i процес повторюється. Однією з перших робіт, які використовували даний принцип $є$ робота Faverjon та Tournassoud [50], у якій розглядається створення проміжних, локальних конфігурацій робота.

Glavina представив рішення проблеми пошуку шляху за допомогою рандомізованої генерації проміжних цілей ([51], рис. 8). Chen та Hwang запропонували нову стратегію під назвою SANDROS [52], у якому проміжні цілі являють собою частини конфігураційного простору, які мають відносно великі відстані до перешкод і, отже, відповідають конфігураціям, які робот може легко досягти за допомогою місцевого планування.

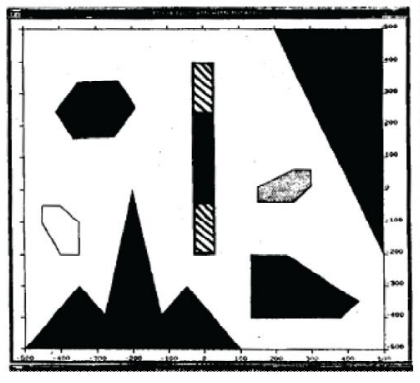

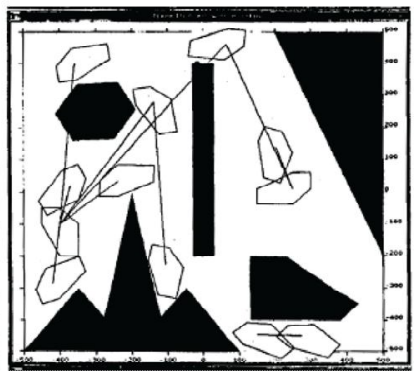

б

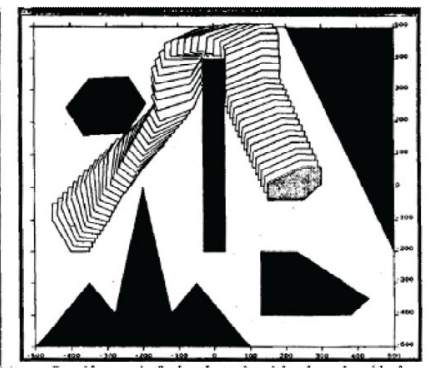

Рис. 8. Отримання шляху для мобільного робота методом, представленим у [51]:

a - стан роботу на перед початком роботи та кінцева конфігурація, б - створення проміжних конфігурацій та поєднання їх у граф, в - знайдений шлях від початку до мети

Tермін «subgoal network» як назва окремої категорії методів планування шляху разом з формальним описом був приведений у [53].

Проблема створення проміжних цілей $є$ проблемою глобального планування, а отже, окрім запропонованого випадкової генерації [52], може вирішуватись за допомогою інших методів планування шляху. Baginski та M. Eldracher розробили алгоритм, який використовує штучну нейронну мережу для пошуку проміжних цілей [53], у [54] представлено генератор проміжних цілей, що використовує штучні потенційні поля, а у [55] - генератор, який базується на RRT.

У методі ієрархічного планування руху [56], який застосовується для людиноподібних роботів, пошук проміжних цілей виконується шляхом проектування корпусу робота в потрібних конфігураціях на двовимірну карту, з подальшим вибором оптимальної проекції.

Запропонований у [57] метод використовує систему комп'ютерного зору для пошуку проміжних цілей.

Після необхідної обробки отриманого зображення, алгоритм використовує метод крутого спуску для пошуку найкоротшого шляху, на якому у свою чергу шукається точка, яка буде використовуватися як проміжна ціль.

\section{Висновки}

У цій роботі проаналізовано 35 різних методів пошуку шляху для мобільного робота. Методи аналізувалися за наступними характеристиками: обмеження; режим планування; метрика, що використовується для планування наступного кроку. Характеристики класичних методів, які було представлено у цій статті показано у табл. 1.

Обмеження на систему для якої може застосовуватись метод, бувають голономними або неголономними. Голономні обмеження можуть застосовуватися до систем, де рух описується лише через координати та час, без прийому до уваги швидкостей та прискорень, що робить іх ідеальними для теоретичних розрахунків. Хоча такі системи існують, більшість існуючих МАР використовують ці показники та $є$ неголономними. Переважна кількість оглянутих методів (25 з 35) розроблялася беручи до умови голономні обмеження, що означає що у багатьох випадках застосування цих методів для не-голономних систем потребує використання додаткової оптимізації. Режим планування показує, чи може даний метод проводити планування під час руху (онлайн), чи до початку руху (офлайн). Навіть методи, що знаходяться у однаковій категорії можуть суттєво відрізнятися залежно від того, для якого режиму вони розроблялися. 
Таблиия 1 - Характеристичні особливості класичних методів пошуку шляху

\begin{tabular}{|c|c|c|c|c|}
\hline Метод & Категорія & Обмеження & Режимпјанування & Метрика \\
\hline $\begin{array}{l}\text { Vertical cellular } \\
\text { decomposition [5] }\end{array}$ & $\begin{array}{c}\text { Клітинна декомпози- } \\
\text { ція } \\
\end{array}$ & Голономні & Офлайн & Евклідова \\
\hline $\begin{array}{l}\text { Boustrophedon cellular } \\
\text { decomposition [6] }\end{array}$ & $\begin{array}{c}\text { Клітинна декомпози- } \\
\text { ція } \\
\end{array}$ & Неголономні & Офлайн & Евклідова \\
\hline Morse decomposition [7] & $\begin{array}{c}\text { Клітинна декомпози- } \\
\text { ція } \\
\end{array}$ & Голономні & Онлайн & Евклідова \\
\hline $\begin{array}{l}\text { Exhaustive path planning } \\
\text { with exact cell decom- } \\
\text { ?osition [9] }\end{array}$ & $\begin{array}{c}\text { Клітинна декомпози- } \\
\text { ція }\end{array}$ & Неголономні & Офлайн & Кумулятивна Евклідова \\
\hline $\begin{array}{l}\text { Approximate cell } \\
\text { decomposition [10] }\end{array}$ & $\begin{array}{c}\text { Клітинна декомпози- } \\
\text { ція } \\
\end{array}$ & Голономні & Офлайн & $A^{*}$ \\
\hline $\begin{array}{l}\text { Sensor path planning with } \\
\text { approximate cell } \\
\text { decomposition [11] }\end{array}$ & $\begin{array}{c}\text { Клітинна декомпози- } \\
\text { ція }\end{array}$ & Неголономні & Онлайн & Залежно від цілі \\
\hline $\begin{array}{l}\text { Quadtree } \square \text { based decom- } \\
\text { ?osition [12] }\end{array}$ & $\begin{array}{c}\text { Клітинна декомпози- } \\
\text { ція } \\
\end{array}$ & Голономні & Онлайн & Евклідова \\
\hline $\begin{array}{l}\text { Framed-quadtree } \\
\text { decomposition [13] }\end{array}$ & $\begin{array}{c}\text { Клітинна декомпози- } \\
\text { ція } \\
\end{array}$ & Неголономні & Офлайн & $\mathrm{D}^{*}$ \\
\hline $\begin{array}{l}\text { K-Framed quadtrees } \\
\text { decomposition [14] }\end{array}$ & $\begin{array}{l}\text { Клітинна декомпози- } \\
\text { ція }\end{array}$ & Неголономні & Офлайн & $A^{*}$ \\
\hline $\begin{array}{l}\text { Adaptive decomposition } \\
{[15]}\end{array}$ & $\begin{array}{c}\text { Клітинна декомпози- } \\
\text { ція } \\
\end{array}$ & Голономні & Онлайн & Евклідова + Вартість \\
\hline $\begin{array}{l}\text { Probabilistic cell } \\
\text { decomposition [16] }\end{array}$ & $\begin{array}{c}\text { Клітинна декомпози- } \\
\text { ція } \\
\end{array}$ & Неголономні & Офлайн & Евклідова \\
\hline $\begin{array}{l}\text { Probabilistic cell } \\
\text { decomposition with } \\
\text { harmonic functions [17] }\end{array}$ & $\begin{array}{c}\text { Клітинна декомпози- } \\
\text { ція }\end{array}$ & Голономні & Офлайн & $\begin{array}{l}\text { Відстань + Значення } \\
\text { гармонічних функцій }\end{array}$ \\
\hline $\begin{array}{l}\text { Artificial potential field } \\
\text { method [18] }\end{array}$ & $\begin{array}{l}\text { Штучне потенційне } \\
\text { поле }\end{array}$ & Голономні & Онлайн & Евклідова + Швидкість \\
\hline $\begin{array}{l}\text { Dynamic artificial potential } \\
\text { field method [19] }\end{array}$ & $\begin{array}{c}\text { Штучне потенційне } \\
\text { поле } \\
\end{array}$ & Голономні & Онлайн & Евклідова + Швидкість \\
\hline $\begin{array}{l}\text { Improved artificial potential } \\
\text { field [20] }\end{array}$ & $\begin{array}{l}\text { Штучне потенційне } \\
\text { поле }\end{array}$ & Голономні & Офлайн & Евклідова \\
\hline Ariadne's clew [27] & Клубок Аріадни & Голономні & Офлайн & Манхеттенська \\
\hline $\begin{array}{l}\text { Expansive configuration } \\
\text { spaces [28] }\end{array}$ & $\begin{array}{c}\text { Експансивні просто- } \\
\text { рові дерева }\end{array}$ & Голономні & Офлайн & Евклідова \\
\hline Probabilistic Roadmaps [31] & Дорожні карти & Голономні & Офлайн & Евклідова \\
\hline $\begin{array}{l}\text { Randomized roadmap } \\
\text { method [32] }\end{array}$ & Дорожні карти & Голономні & Офлайн & Евклідова \\
\hline Lazy PRM [37] & Дорожні карти & Голономні & Офлайн & $A^{*}$ \\
\hline $\begin{array}{l}\text { Gaussian sampling for PRM } \\
\text { [38] }\end{array}$ & Дорожні карти & Голономні & Офлайн & Зважена евклідова \\
\hline $\begin{array}{l}\text { Halton sampling for PRM } \\
\text { [39] }\end{array}$ & Дорожні карти & Голономні & Онлайн & $A^{*}$ \\
\hline RRT [41] & RRT & Неголономні & Офлайн & Евклідова \\
\hline RRT-connect [42] & RRT & Неголономні & Офлайн & Евклідова \\
\hline RRT with local trees [44] & RRT & Неголономні & Офлайн & Евклідова+Манхеттенська \\
\hline Obstacle-based RRT [45] & RRT & Неголономні & Офлайн & Евклідова + Жадібна \\
\hline Bidirectional RRT [46] & RRT & Голономні & Офлайн & Евклідова + Вартість \\
\hline $\mathrm{RRT}^{*}[47]$ & RRT & Голономні & Офлайн & Евклідова \\
\hline Informed RRT* [48] & RRT & Голономні & Офлайн & Евклідова \\
\hline $\begin{array}{l}\text { Goal-directed and } \\
\text { randomized search[52] }\end{array}$ & Subgoal network & Голономні & Онлайн & Евклідова \\
\hline SANDROS [52] & Subgoal network & Голономні & Онлайн & Евклідова+Манхеттенсыка \\
\hline $\begin{array}{l}\text { Artificial potential field } \\
\text { based subgoal network [54] }\end{array}$ & Subgoal network & Голономні & Онлайн & Евклідова + Вартість \\
\hline $\begin{array}{l}\begin{array}{l}\text { Dynamic subgoal path } \\
\text { planner [55] }\end{array} \\
\end{array}$ & Subgoal network & Голономні & Онлайн & A* + Евклідова \\
\hline $\begin{array}{l}\text { Hierarchical motion planner } \\
\text { [56] }\end{array}$ & Subgoal network & Голономні & Онлайн & Евклідова + Вартість \\
\hline $\begin{array}{l}\text { Two-layered subgoal } \\
\text { algorithm [57] }\end{array}$ & Subgoal network & Голономні & Онлайн & A* + Евклідова \\
\hline
\end{tabular}


Це можна пояснити різницею у форматі вхідних даних, що потребується для роботи методу: офлайн методи використовують існуюче представлення простору $C_{\text {space }}$ як масивів перешкод та простору $C_{\text {free, }}$ a онлайн методи використовують сенсорні дані для побудови представлення простору для подальшого руху. Значна кількість методів (22 з 35) розроблені для пошуку шляху у режимі офлайн та не можуть бути використані для пошуку за умов відсутності повної мапи на момент початку шляху. Це означає, що для застосування цих методів потрібно передбачити можливість створення локальної мапи оточення МАР використання мережі проміжних задач для подальшої навігації.
Під метрикам алгоритмів пошуку шляху маються на увазі методи отримання кращого розв'язку для поточного кроку алгоритму, або для алгоритму взагалі. Це можуть бути як прості метрики, такі як Евклідова чи Манхеттенська відстань до об'єкту, так і алгоритми пошуку найкоротшого шляху на графі та функції вартості. 335 методів, 14 використовують лише Евклідову довжину у якості метрики для пошуку, та ще 13 - комбінацію з Евклідової метрики та іншого методу оцінки.

Це означає, що ці методи можна вдосконалити за рахунок використання інтелектуальних систем, таких як нейронні мережі та нечіткі регулятори [21, $22,43,53]$.

\section{СПИСОК ЛІТЕРАТУРИ}

1. Causes of Coal Mine Accidents in the World and Turkey/ Küçük, F., and Ilgaz, A. // Turkish thoracic journal - Vol. 16. P. 9-14. - 2015. https://doi.org/10.5152/ttd.2015.003

2. An affordable, robust mining inspection robot / CD. A. Carnegie, J. McVay, L. Molyneaux and C. Chitty // 2015 IEEE 7 th International Conference on Cybernetics and Intelligent Systems (CIS) and IEEE Conference on Robotics, Automation and Mechatronics (RAM) - P. 143-148 - 2015. https://doi.org/10.1109/ICCIS.2015.7274611

3. Mobile robots in mine rescue and recovery/ R. R. Murphy, J. Kravitz, S. L. Stover and R. Shoureshi // IEEE Robotics \& Automation Magazine - Vol. 16. - No. 2. - P. 91-103. - 2009. https://doi:10.1109/MRA.2009.932521

4. Gross motion planning - a survey/ Yong K. Hwang and Narendra Ahuja // ACM Computing Surveys (CSUR) - Vol. 24. No. 3. - P. 219-291 - 1992. https://doi.org/10.1145/136035.136037

5. Robot Motion Planning: A Distributed Representation AProach /Barraquand Jerome and Latombe Jean-Claude // International Journal of Robotic Research - IJRR - Vol. 10. - P. 628-649. - 1991. https://doi.org/10.1177/027836499101000604

6. Coverage of Known Spaces: The Boustrophedon Cellular Decomposition / Choset, H // Autonomous Robots - Vol. 9. P. 247-253 - 2000. doi.org/10.1023/A:1008958800904

7. Sensor-Based Coverage: Incremental Construction of Cellular Decompositions/ Yong K. Hwang and Narendra Ahuja // Algorithmic Foundations of Robotics V. Springer Tracts in Advanced Robotics - Vol. 7. - P. 399-415 - 2004. https://doi.org/10.1007/978-3-540-45058-0_24

8. Optimizing cell decomposition path planning for mobile robots using different metrics/ M. Kloetzer, C. Mahulea and R., Gonzalez // 2015 19th International Conference on System Theory, Control and Computing (ICSTCC) - P. 565-570 - 2015. https://doi.org/10.1109/ICSTCC.2015.7321353

9. Path tracking control coverage of a mining robot based on exhaustive path planning with exact cell decomposition/ D. H. Kim et al. // 2014 14th International Conference on Control, Automation and Systems (ICCAS 2014) - P. 730-735 2014. https://doi.org/10.1109/ICCAS.2014.6987875.

10. A subdivision algorithm in configuration space for findpath with rotation/ R. A. Brooks and T. Lozano-Pérez // IEEE Transactions on Systems, Man, and Cybernetics - Vol. SMC-15. - No. 2. - P. 224-233 - 1985. https://doi.org/10.1109/TSMC.1985.6313352

11. Information-Driven Sensor Path Planning by AProximate Cell Decomposition/ C. Cai and S. Ferrari // IEEE Transactions on Systems, Man, and Cybernetics, Part B (Cybernetics) - Vol. 39. - No. 3. - P. 672-689 - 2009. https://doi.org/10.1109/TSMCB.2008.2008561

12. A quadtree $\square$ based path $\square$ planning algorithm for a mobile robot / Noborio Hiroshi , Naniwa Tomohide and Arimoto Suguru // Journal of Robotic Systems - Vol. 7. - P. 219-291. - 1990. https://doi.org/10.1002/rob.4620070404

13. Framed-quadtree path planning for mobile robots operating in sparse environments / A. Yahja, A. Stentz, S. Singh and B. L. Brumitt // Proceedings. 1998 IEEE International Conference on Robotics and Automation - Vol. 1. - P. 650-655. - 1998. https://doi.org/10.1109/ROBOT.1998.677046

14. The K-Framed Quadtrees AProach for Path Planning Through a Known Environment / Rodrigues A., Costa P. and Lima J. // ROBOT 2017. Advances in Intelligent Systems and Computing - Vol. 693. - P. 49-59 - 2018. https://doi.org/10.1007/9783-319-70833-1 5

15. Adaptive online cell decomposition with a laser range finder in unknown non-rectilinear environments, B., Lee, S.-G., Quang, T. B., Gwak, K.-W., and Lee, B. // International Journal of Precision Engineering and Manufacturing Vol. 18(4). - P. 487-495 - 2017. https://doi.org/10.1007/s12541-017-0059-7

16. Path planning using probabilistic cell decomposition / Lingelbach, F. // 2004 IEEE International Conference on Robotics and Automation - P. 467-472. - 2004. https://doi.org/10.1109/ROBOT.2004.1307193

17. Path planning using Harmonic Functions and Probabilistic Cell Decomposition / Rosell, J., and Iniguez, P. // Proceedings of the 2005 IEEE International Conference on Robotics and Automation - P. 1803-1808. - 2005. https://doi.org/10.1109/ROBOT.2005.1570375

18. Real-time obstacle avoidance for manipulators and mobile robots / O. Khatib // Proceedings. 1985 IEEE International Conference on Robotics and Automation - P. 500-505. - 1985. https://doi.org/10.1109/ROBOT.1985.1087247

19. Dynamic motion planning for mobile robots using potential field method / Ge, S., and Cui, Y. // Autonomous Robots Vol. 13. - P. 207-222. - 2002. https://doi.org/10.1023/A:1020564024509

20. An efficient improved artificial potential field based regression search method for robot path planning / Li, G., Yamashita, A., Asama, H., and Tamura, Y. // 2012 IEEE International Conference on Mechatronics and Automation - P. 1227-1232. 2012. https://doi.org/10.1109/ICMA.2012.6283526 
21. Evolutionary artificial potential fields and their aPlication in real time robot path planning / P. Vadakkepat, Kay Chen Tan and Wang Ming-Liang // ACM Computing Surveys (CSUR) - Vol. 1. - P. 256-263. - 2000. https://doi.org/10.1109/CEC.2000.870304

22. Autonomous mobile robot dynamic motion planning using hybrid fuzzy potential field / Jaradat, M. A. K., Garibeh, M. H., \& Feilat, E. A. // Soft Computing - Vol. 16(1). - P. 153-164. - 2012. https://doi.org/10.1007/s00500-011-0742-z

23. Multiple robot path coordination using artificial potential fields / C. W. Warren // Proceedings., IEEE International Conference on Robotics and Automation - Vol. 1. - P. 500-505. - 1990. https://doi.org/10.1109/ROBOT.1990.126028

24. A study of cluster robots line formatted navigation using potential field method / Y. H. Kang, M. C. Lee, C. Y. Kim, S. M. Yoon and C. B. Noh // 2011 IEEE International Conference on Mechatronics and Automation - P. 1723-1728. - 2011. https://doi.org/10.1109/ICMA.2011.5986370

25. Sampling-Based Robot Motion Planning: A Review / M. Elbanhawi and M. Simic // IEEE Access - Vol. 2. - P. 56-77. 2014. https://10.1109/ACCESS.2014.2302442

26. Robot Motion Planning: A Distributed Representation AProach / Barraquand, J. and Latombe, J.C. // The International Journal of Robotics Research - Vol. 10(6). - P. 628-649. - 1991. https://doi.org/10.1177/027836499101000604

27. The "Ariadne's clew" algorithm: global planning with local methods / P. Bessiere, J., Ahuactzin, E., Talbi and E. Mazer // Proceedings of 1993 IEEE/RSJ International Conference on Intelligent Robots and Systems (IROS '93) - Vol. 3. - P. 13731380. - 1993. https://doi.org/10.1109/IROS.1993.583784

28. Path planning in expansive configuration spaces / D. Hsu, J.Latombe and R. Motwani // Proceedings of International Conference on Robotics and Automation - Vol. 3. - P. 2719-2726. - 1997. https://doi.org/10.1109/ROBOT.1997.619371

29. Visibility-polygon search and euclidean shortest paths / T. Asano, T. Asano, L. Guibas, J. Hershberger and H. Imai // 26th Annual Symposium on Foundations of Computer Science (sfcs 1985) - P. 155-164. - 1985. https://doi.org/10.1109/SFCS.1985.65

30. A Voronoi method for the piano-movers problem, Proceedings / J. Canny // 1985 IEEE International Conference on Robotics and Automation - P. 530-535. - 1985. https://doi.org/10.1109/ROBOT.1985.1087297

31. Probabilistic roadmaps for path planning in high-dimensional configuration spaces / L. E. Kavraki, P. Svestka, J. Latombe and M. H. Overmars //IEEE Transactions on Robotics and Automation - Vol. 12. - No.4. - P. 566-580 - 1996. https://doi.org/10.1109/70.508439

32. A randomized roadmap method for path and manipulation planning / N. M. Amato and Y. Wu // Proceedings of IEEE International Conference on Robotics and Automation - Vol. 1. - P. 113-120. - 1996. https://doi.org/10.1109/ROBOT.1996.503582

33. Probabilistic roadmaps for robot path planning / Kavraki, L. E., Latombe, J. C., and Latombe, E. // Practical Motion Planning in Robotics: Current AProaches and Future. - 1998. https://doi.org/10.1.1.19.5276

34. Probabilistic Road Map sampling strategies for multi-robot motion planning / Clark, C. M. // Robotics and Autonomous Systems - Vol. 53(3-4). - P. 244-264 - 2005. https://doi.org/10.1016/j.robot.2005.09.002

35. Coordinated path planning for multiple robots / Švestka, P., \& Overmars, M. H. // Robotics and Autonomous Systems Vol. 23(3). - P. 125-152. - 1998. https://doi.org/10.1016/S0921-8890(97)00033-X

36. Multiple query probabilistic roadmap planning using single query planning primitives / Bekris, K. E., Chen, B. Y., Ladd, A. M., Plaku, E., and Kavraki, L. E. // Proceedings 2003 IEEE/RSJ International Conference on Intelligent Robots and Systems (IROS 2003) - P. 656-661. - 2003. https://doi.org/10.1109/IROS.2003.1250704

37. Path planning using lazy PRM / R. Bohlin and L. E. Kavraki // Proceedings 2000 ICRA. Millennium Conference. IEEE International Conference on Robotics and Automation. Symposia Proceedings - Vol. 1. - P. 521-528. - 2000. https://doi.org/10.1109/ROBOT.2000.844107

38. The Gaussian sampling strategy for probabilistic roadmap planners / V. Boor, M. H. Overmars and A. F. van der StaPen // Proceedings 1999 IEEE International Conference on Robotics and Automation - P. 1018-1023. - 1999. https://doi.org/10.1109/ROBOT.1999.772447

39. Mobile robot navigation system based on Probabilistic Road Map (PRM) with Halton sampling of configuration space /Velagic, J., Delimustafic, D., \& Osmankovic, D. // 2014 IEEE 23rd International Symposium on Industrial Electronics (ISIE) - P. 1227-1232. - 2014. https://doi.org/10.1109/ISIE.2014.68647

40. The bridge test for sampling narrow passages with probabilistic roadmap planners / Hsu, D., Jiang, T., Reif, J., and Sun, Z. // IEEE International Conference on Robotics and Automation, 2003. Proceedings. ICRA '03 - Vol. 3. - No. 3. P. 4420-4426. - 2003. https://doi.org/10.1109/ROBOT.2003.1242285

41. Rapidly-Exploring Random Trees: A New Tool for Path Planning / LaValle, S. M. // 1998. https://doi.org/10.1.1.35.1853

42. RRT-connect: An efficient aProach to single-query path planning / Kuffner, J. J., and LaValle, S. M. (2000) // Proceedings 2000 ICRA. Millennium Conference. IEEE International Conference on Robotics and Automation - Vol. 2. - P. 995-1001. 2000. https://doi.org/10.1109/ROBOT.2000.844730

43. AProaches for heuristically biasing RRT growth / Urmson, C., and Simmons, R. // Proceedings 2003 IEEE/RSJ International Conference on Intelligent Robots and Systems (IROS 2003) - Vol. 2. - P. 1178-1183. - 2003. https://doi.org/10.1109/IROS.2003.1248805

44. Augmenting RRT-planners with local trees / Strandberg, M. // IEEE International Conference on Robotics and Automation Vol. 4. - P. 3258-3262. - 2004. https://doi.org/10.1109/ROBOT.2004.1308756

45. An obstacle-based rapidly-exploring random tree / Rodríguez, S., Tang, X., Lien, J. M., and Amato, N. M. // IEEE Inter?ational Conference on Robotics and Automation - P. 895-900. - 2006. https://doi.org/10.1109/ROBOT.2006.1641823

46. Optimal Bidirectional Rapidly-Exploring Random Trees / Jordan, M., and Perez, A. // Computer Science and Artificial Intelligence Laboratory - 2013.

47. Sampling-based algorithms for optimal motion planning / Karaman, S., and Frazzoli, E. // The International Journal of Robotics Research - Vol. 30(7). - P. 846-894. - 2011. https://doi.org/10.1177/0278364911406761

48. Informed RRT*: Optimal sampling-based path planning focused via direct sampling of an admissible ellipsoidal heuristic / J. D. Gammell, S. S. Srinivasa and T. D. Barfoot // 2014 IEEE/RSJ International Conference on Intelligent Robots and Systems - P. 2997-3004. - 2014. https://doi.org/10.1109/IROS.2014.6942976 
49. Rapidly-exploring random tree based memory efficient motion planning / O. Adiyatov and H. A. Varol // 2013 IEEE International Conference on Mechatronics and Automation - P. 354-359. -2013. https://doi.org/10.1109/ICMA.2013.6617944

50. A local based aProach for path planning of manipulators with a high number of degrees of freedom /Faverjon, B., and Tournassoud, P. // Proceedings. 1987 IEEE International Conference on Robotics and Automation - Vol. 4. - P. 1152-1159. - 1987. https://doi.org/10.1109/ROBOT.1987.1087982

51. Solving findpath by combination of goal-directed and randomized search / Glavina, B. // 1990 IEEE International Conference on Robotics and Automation - Vol. 3. - P. 1718-1723. - 1990. https://doi.org/10.1109/ROBOT.1990.126257

52. SANDROS: a motion planner with performance proportional to task difficulty / Chen, P. C., \& Hwang, Y. K. // Proceedings 1992 IEEE International Conference on Robotics and Automation - P. 2346-2353. - 1992. https://doi.org/10.1109/ROBOT.1992.220112

53. Path planning with neural subgoal search/ B. Baginski and M. Eldracher // Proceedings of 1994 IEEE International Conference on Neural Networks (ICNN'94) - Vol. 5. - P. 2732-2736. - 1994. https://doi.org/10.1109/ICNN.1994.374662

54. Robot Real-Time Motion Planning and Collision Avoidance in Dynamically Changing Environments / Jin-xue Z. // Emerging Research in Artificial Intelligence and Computational Intelligence, Communications in Computer and Information Science - Vol. 237. - P. 325-334. - 2011. https://doi.org/10.1007/978-3-642-24282-3 44

55. A dynamic subgoal path planner for unpredictable environments / H. Liu, W. Wan and H. Zha // 2010 IEEE International Conference on Robotics and Automation - P. 994-1001. - P. 219-291 - 2010. https://doi.org/10.1109/ROBOT.2010.5509324

56. An improved hierarchical motion planner for humanoid robots / Candido, S., Kim, Y. T., and Hutchinson, S. // 2008 8th IEEE-RAS International Conference on Humanoid Robots, Humanoids 2008 - P. 654-661. - 2008. https://doi.org/10.1109/ICHR.2008.4756021

57. A two-layered subgoal based mobile robot navigation algorithm with vision system and IR sensors / Nirmal Singh, N., Chatterjee, A., Chatterjee, A., and Rakshit, A. // Measurement: Journal of the International Measurement Confederation Vol. 44(4). - P. 620-641. - 2011. https://doi.org/10.1016/i.measurement.2010.12.002

Рещензент: д-р техн. наук, проф. К. С. Козелкова, Державний університет телекомунікацій, Київ Received (Надійшла) 27.03.2019

Accepted for publication (Прийнята до друку) 22.05.2019

\section{Классические методы планирования пути для мобильных роботов}

А. А. Проценко, В. Г. Іванов

Мобильные автономные роботы (МАР) используются для выполнения большого количества разнообразных задач в различных отраслях, таких как добыча полезных ископаемых, поиск и спасение, военных применений и тому подобное. Отдельно выделяется категория МАР, которые используются в закрытых помещениях. Это связано с дополнительными техническими и программными ограничениями налагаемые на МАР и оператора. В этой статье рассматриваются 35 классических методов поиска пути для МАР и методов их оптимизации. Классические методы включают следующие категории методов: методы клеточной декомпозиции; методы искусственного потенциального поля; выборочные методы; методы, использующие сеть промежуточных задач. В статье также рассматриваются основные проблемы, возникающие при исполнении задачи поиска путей. Методы анализировались по следующим характеристикам: ограничения; режим планирования; мнтрика, которая используется для планирования следующего шага. Также в статье рассматриваются основные проблемы, с которыми сталкиваются при выполнении задачи поиска пути.

Кл ючевы е слов а: МАР, работы, автономность, поиск пути, планирование движения.

\section{Classical methods of path planning for mobile robots}

\section{A. A. Protsenko, V. G. Ivanov}

Mobile autonomous robots (MAR) are used to perform a large number of diverse tasks in various industries, such as mining, search and rescue, military, etc. Separately allocated category of MAR, which is used in enclosed spaces. This is due to the additional technical and software limitations that are imposed on the MAR and the operator. The problem of moving robots from point $A$ to point $B$ is a basic problem that applies to all robots, but when used in underground structures, the solution to this problem is complicated by the presence of additional factors such as lack of communication with the operator and the inability to use GPS systems. This article discusses 35 classic methods of pathfinding for MAR and methods for optimizing them. Classical methods find solutions to the problem of finding a way, or prove that it does not exist, without finding a compromise between the quality of the path and the amount of time / resources required to find it. Classical methods include the following categories of methods: methods of cell decomposition; methods of the artificial potential field; selective methods; methods that use a subgoal network. The article also discusses the main problems encountered during the execution of the pathfinding task. Methods were analyzed for the following characteristics: restrictions; planning mode; the metric used to plan the next step. The limitations on a system for which the method may be used are either holonomic or non-holonomic. Holonomic restrictions can be applied to systems where motion is described only through coordinates and time, without taking into account speeds and accelerations, which makes them ideal for theoretical calculations. The planning mode shows whether this method can be used for planning on-the-go (online) or before it starts (offline). Even methods that are in the same category may vary significantly depending on which mode they were designed for. Under the metrics of path search algorithms, we mean methods for obtaining a better solution for the current step of the algorithm, or for the algorithm in general.

Keywords: MAR, robot, autonomy, path search, motion planning. 